\title{
CONTEMPORARY IDENTIFICATION OF FUTURE LEADERS IN THE AFFIRMATION OF HUMAN RESOURCES
}

\section{Aleksandar Gracanac}

The Faculty of Entrepreneurial Business and Real Estate Management, University "Union - Nikola Tesla", Belgrade, Serbia

https://orcid.org/0000-0002-3018-2912

\section{Dragana Djokic}

University “Union - Nikola Tesla”, Belgrade, Serbia

https://orcid.org/0000-0002-2974-384X

\author{
Vladimir Djokic \\ University “Union - Nikola Tesla”, Belgrade, Serbia
}

CMESTE

JEL Category: 015

\begin{abstract}
Globalization, the third phase of the internationalization process of capital, technological innovation, and human resources, has started the second decade of transitional changes in future business activities. Recently, such an environment of different levels of development and influence (capital, innovation, and human resources) has led to global challenges of risk management predictability and of developing next generation leaders in complex international business partnerships, in relation to both multinational companies and continents. Rapid technological innovation has raised living standards and improved the quality of life. On the other hand, it might also lead to imbalance between human resource and new job demands, based on entrepreneurship as a way of life, in all forms - social, female, youth entrepreneurship. These events might lead to implementing a start-up entrepreneurship methodology, to involve and inspire the next generation of numerous educated young entrepreneurs in the world. This increasing dedication to future young entrepreneurs, based on institutional, corporative, and strategic state measures, meant for the next decade of globalized economy, has inevitably initiated more humane and altruistic business management of the $21^{\text {st }}$ century. At the same time, the activities of non-profit institutions have appeared, such as the foundations that are established to preserve, nurture, and increase altruism and corporate ethical values, in accordance with environmental protection and global ecosystem awareness.
\end{abstract}

The address of the corresponding author: Aleksandar Gračanac 表”agracanac@unionnikolatesla.edu.rs
Keywords: $\quad$ globalization, leadership, human resource management, entrepreneurship, start-up business, buesiness and the environment. 


\section{INTRODUCTION}

Entrepreneurship and employment of micro, small and medium-sized enterprises account for $98 \%$ of the world-global economy and $99.9 \%$ of the EU, which follows the trends in resources, in accordance with the extent the countries are committed to entrepreneurship as a way of life. Differences in entrepreneurship development are a consequence of non-standard processes, which are not followed for multiple reasons; technicaltechnological, financial, and human resources performance, which inevitably reflected on employment. (Gracanac, 2012)

Entrepreneurship can help young leaders show their creativity, skills and acquired knowledge, speeding up their goal achievement. According to the current world economic situation, human resources are regarded as a decisive factor in the realization of business innovations and investment ventures. (Gračanac, 2019) Nowadays, the global economy is facing major challenges, like the lack of adequate business leaders. Numerous scientific institutions and foundations, established to improve human resources, have been applying a wide variety of methods and approaches, to eliminate the key employee risks.

Global business changes have imposed a new development policy, which is manifested in entrepreneurship by new professions, and according to the World Economic Forum, 97\% of new jobs created from the needs of market demands will be distributed from the sector of micro, small and medium enterprises, which paves the way for future young leaders. The consequences of such events are predicted by the analyses conducted by the world consulting company Ernst \& Young, claiming that new entrepreneurial occupations, within large and small enterprises, will increase business stability three times. The consulting firm McKinsey came up with the following research findings. Namely, for ten countries that were observed in the period of the last two years, the increase in the number of started start-up businesses brought 3 trillion dollars or a growth of economic activities of $20 \%$. (Clark, 2020)

The imperative of globalized economy today is the availability of young leaders, the new generation managers who have been introducing new business models and occupations.
The mission of one of the world's leading foundations for youth entrepreneurship - (The Global Education \& Leadership Foundation tGELF USA) (Gračanac, 2001) is to affirm world future business leaders. Its primary goal is identifying and financially supporting young future leaders around the world, cultivating ethical and altruistic values of future leaders, promoting continuity of youth leadership competitions, as sporting events, with the branded digital platform ESG. The Foundation promotes the education of young leaders and the exchange of knowledge and experiences. For years, the Foundations has been present and successful in business, promoting entrepreneurship in more than 200 countries around the world. When it comes to its realized activities, the Foundation has promoted and empowered more than 175,000 young entrepreneurs around the world, especially in founding start-ups, and through the Entrepreneurship World Cup. (tGELF, 2020)

Regarding the application of the latest technological innovations, the management of the Foundation is ahead of similar foundations, and its exceptionality is reflected in the application of digital marketing. Nowadays, digital marketing is an indispensable part of business all over the world. It significantly affects the overall result. Without the application or use of digital marketing and skills, competitiveness and market visibility is quickly threatened. Digital marketing adds values to any business in a huge number of ways.

In the field of leadership, the emphasis of global companies is placed on the early detection of candidates with distinctive leadership characteristics and, through the organization of various programs, their orientation towards the development of leadership skills. The paper identifies three business practices as the most used and represented: travel and transfers, teamwork in heterogeneous teams and training programs.

Leadership is not merely management of an organization, although it is associated with it and is important for every company. It has been observed that there is too much management and too little leadership in most companies. A successful manager is usually a good planner, an organized manager but without necessary motivational skills of a leader. Successful leaders can stimulate the mood and commitment of their employees. 
What people of some organization within a company want from their leader is to provide answers to the following questions: "Where are we going?" "How do we get there?" "What is my role?" Proper use of leadership skills and their improvement helps the team understand the responsibility of the work in an unpredictable business world. The Global Education and Leadership Foundation is also led by these principles in the Balkans and is currently expanding its mission to all continents.

In December 2020, the Global Education \& Leadership Foundation (GELF), through the founded ESG Serbia, (a member of the international jury on behalf of Serbia is the University Union Nikola Tesla), began its mission in the Balkans, continuing its long-term mission, organized according to dynamics, competitions for future young leaders, which are to be held the next year. (tGELF, 2020)

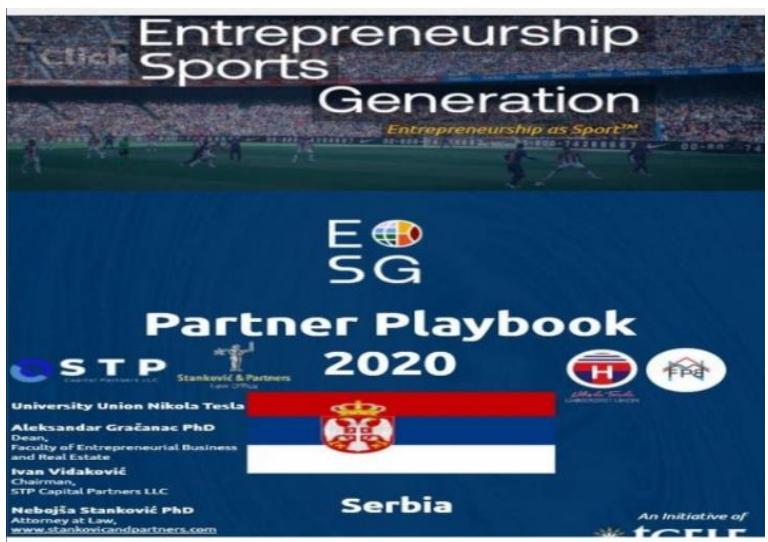

Fig. 1 GELF \& ESG partners - Serbia

Using the ESG platform, the Foundation animates, monitors, and invites potential future young business leaders - graduate managers, engineers, architects, from various universities, institutions and companies - to present their innovative ideas in a wide range of areas. Organized competitions include the process of applying, educational training, participation in competitions and final selective groups and winning prizes, in accordance with several different levels and criteria.

Based on their business activities and achieved career success, professors of the Faculty of Entrepreneurial Business and Real Estate Management create and deliver lectures and provide good practice teaching for future entrepreneurship leaders, within the organization mission of ESG Serbia.
Accordingly, the Faculty of Entrepreneurial Business and Real Estate Management conducted an initiative survey at the University Nikola Tesla, among the students of the third and fourth year, in the period from December 15, 2020 , to February 1, 2021, in accordance with the activities of GELF Serbia.

It turned out that it is necessary to apply continuous learning and cooperation with companies to prepare future competition candidates, along with educational trainings, aimed at stimulating future managers to apply the acquired knowledge and skills and face the risks imposed by the current global economy.

The objective of this research deals with the analysis of potential capacities of future graduate entrepreneurship managers, their awareness of the situation, requirements, and conditions of the market. Based on the answers, the conducted survey identified the candidates who could meet the criteria of the ESG competition in the coming period, in accordance with the priorities and market needs.

\section{SURVEY}

\section{Question 1:}

When you graduate from the Faculty of Entrepreneurial Business and Real Estate Management at the University Union Nikola Tesla, what requirements do you think you would need to meet to achieve your goals and start your own business?

What needs to be fulfilled in order for you to start your own business?

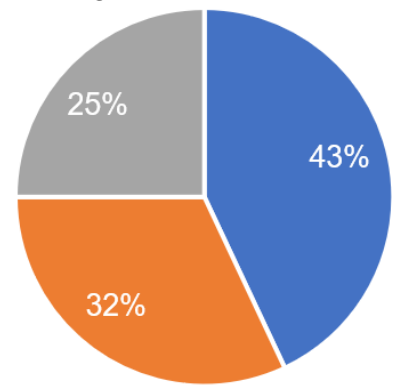

- Financial support (parents, state institutions, foundations...)

- Ambience for entrepreneurship and starting your own business - Technical support of institutions

Fig. 2 Graphical representation of the students answers to the first question 
Out of total number of survey participants (100), 91 answered. Based on the received responses, the following data were obtained:

- Financial support (parents, state institutions, foundations...) $43 \%$

- Ambience for entrepreneurship and starting your own business $32 \%$

- Technical support of institutions $25 \%$

\section{Question 2:}

Are you familiar with the institutions in the country that offer favorable financial resources to encourage graduate managers to start a business?

- I do not know any institution (83\%)

- Friends and colleagues have informed them about a Development Fund, but it is not limited to financing the beginners (11\%)

- They have heard about the existence of some institutions, but they do not know their exact names $(5 \%)$

- Their colleagues have informed them about the Innovation Fund (1\%)

Are you familiar with the institutions in the country that offer favorable financial resources in order to encourage graduate managers to start a business?

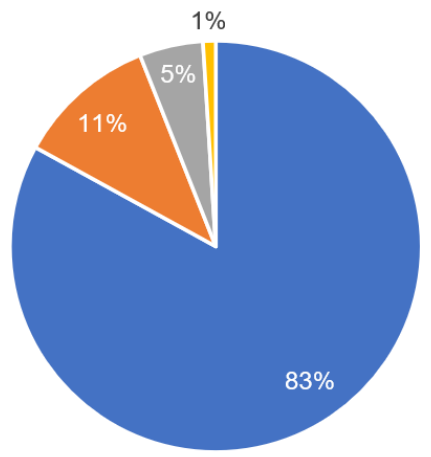

- I do not know any institution

- Friends and colleagues have informed me about a Development Fund

- I have heard about the existence of some institutions, but I do not know their exact names

- My colleagues have informed them about the Innovation Fund

\section{Fig. 3 Graphical representation of the students} answers to the second question

\section{Question 3:}

Have you ever thought about starting your own business?

- I have never thought about that (12\%)

- I have an idea (31\%)

- I lam thinking about becoming an entrepreneur (39\%)
I have been thinking about it, but start-up business risks are considerable (18\%)

The survey showed that it is necessary to improve the institutional development of entrepreneurship, by creating an entrepreneurial environment at a higher

Have you ever thought about starting your own business?

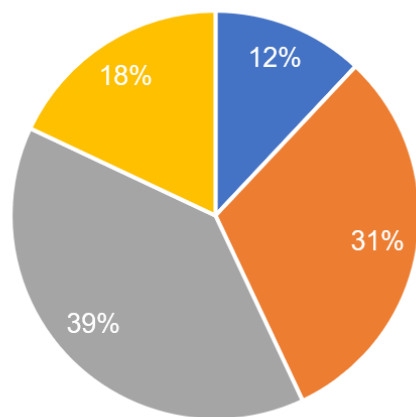

- I have never thought about that

- I have an idea

- I am thinking about becoming an entrepreneur

- I have been thinking about it, but start-up business risks are considerable

Fig. 4 Graphical representation of the students answers to the third question 4

level and providing continuous activities to establish many financial and alternative institutions, aimed at financing start-up businesses. Special attention is paid to the examples of good practice. At the same time, future young entrepreneurs should be enabled to participate in new approaches, project activities of the faculty in business cooperation with entrepreneurs, to develop awareness of entrepreneurship and the spirit of entrepreneurship and become independent young entrepreneurs in the future.

\section{CONCLUSIONS}

According to the estimates of the World Economic Forum, the next third decade of Globalization will be marked by even more sophisticated technologies and entrepreneurship at the highest level, which will bring about 1 billion new jobs and occupations by 2030 . The latest technological achievements in entrepreneurship will mark digital marketing as a necessary condition for development of individuals, companies and stateowned institutions, which will open new perspectives for future global young leaders in preserving and developing high ethical standards in business, in accordance with environmental protection and awareness. 
Also, all the necessary activities in monitoring and financial empowerment of young leaders, based on education and experience, will continue, along with the support of numerous institutions educational, state-owned, and non-profit ones such as the Foundation for Stimulating Youth Entrepreneurship.

The leader is the creator of the mission and the visionary of the organization. A leader must enjoy absolute professional authority among employees. Leaders must be able to impose their authority on the team, build trust and be maximally committed to their work. There is a great need for global leaders in global companies and it is mostly unsatisfied. There is a general opinion that the existing leaders of these companies should work on improving their skills and knowledge before dealing with leadership in a global context. It is becoming increasingly difficult for the companies to accept that human capital is regarded as the most important capital of the 21 st century and that financial and material resources are needed but insufficient to reach a leading position in the global framework.

\section{WORKS CITED}

Clark, P. (2020, 03 26). How managed services can free you to go out and create waves. Retrieved from Innovation \& Delivery Centre London: www.ey.com/en_rs/managed-services

Gracanac, A. (2012). Small Business Act, EU factor of successful management in small and mediumsized enterprises in Serbia. Proceedings of the International Scientific ConferenceMANAGEMENT 2012 (pp. 219-223). Belgrade: Univerzitet Union Beograd.

Gračanac, A. (2001). Svetskotržište u uslovima globalizacije / The World Market in Globalization. Belgrade: Privredna Komora Jugoslavije.

Gračanac, A. (2019, Jan 15). Technical specialism of human resources as condition for development of SME-s in Serbia, Chamber of Commerce of Serbia. (Z. Čekerevac, Ed.) FBIM Transactions, $7(1), 61-66$.

tGELF. (2020, 11 09). Entrepreneurship Sports Generation. Retrieved from Fakultet za preduzetnički biznis i menadžment nekretnina: https://www.facebook.com/pg/FPBMN/posts/

Received for publication: $\quad$ 09.06.2021

Revision received: $\quad$ 23.06.2021

Accepted for publication: $\quad$ 06.07.2021

\section{How to cite this article?}

Style - APA Sixth Edition:

Gracanac, A., Djokic, D., \& Djokic, V. (2021, July 15). Contemporary identification of future leaders in the affirmation of human resources. (Z. Cekerevac, Ed.) MEST Journal, 9(2), 22-27. doi:10.12709/mest.09.09.02.04

Style - Chicago Sixteenth Edition:

Gracanac, Aleksandar, Dragana Djokic, and Vladimir Djokic. 2021. "Contemporary identification of future leaders in the affirmation of human resources." Edited by Zoran Cekerevac. MEST Journal (MESTE) 9 (2): 22-27. doi:10.12709/mest.09.09.02.04.

Style - GOST Name Sort:

Gracanac Aleksandar, Djokic Dragana and Djokic Vladimir Contemporary identification of future leaders in the affirmation of human resources [Journal] // MEST Journal / ed. Cekerevac Zoran. Belgrade - Toronto : MESTE, July 15, 2021. - 2 : Vol. 9. - pp. $22-27$. 
Style - Harvard Anglia:

Gracanac, A., Djokic, D. \& Djokic, V., 2021. Contemporary identification of future leaders in the affirmation of human resources. MEST Journal, 15 July, 9(2), pp. 22-27.

Style - ISO 690 Numerical Reference:

Contemporary identification of future leaders in the affirmation of human resources. Gracanac, Aleksandar, Djokic, Dragana and Djokic, Vladimir. [ed.] Zoran Cekerevac. 2, Belgrade - Toronto : MESTE, July 15, 2021, MEST Journal, Vol. 9, pp. 22-27. 